3. Foucault Michel. Two Lectures. Power/Knowledge. New York: Pantheon Books, 1980. P. 78-108.

4. Harris Laura Alexandra. Queer Black feminism: the pleasure principle. Feminist Review. 1996. 54. P.3-30

5. Humphrey Chris. The politics of carnival: festive Misrule in Medieval England. Manchester: Manchester UP, 2001.

6. Lewis Vashti Crutcher. African tradition in Toni Morrison's Sula. Phylon. 1960. 48.1 P.91-97.

7. McDowell Deborah. "It's not safe. Not safe at all": sexuality in Nella Larsen's Passing. The Lesbian and Gay Studies Reader. New York: Routledge, 1993. P.616-625.

8. McDowell Deborah. New directions in Black feminist criticism. African American literary theory: a reader. New York: New York UP, 2000. P.167-177.

9. Morrison Toni. Sula. New York: Vintage, 2004.

10. Smith Barbara. "Toward a Black feminist criticism." The new feminist criticism: essays on women, literature and theory. New York: Pantheon Books, 1985.

11. Stokes Mason. White heterosexuality: a romance of the straight man' burden. New York: Routledge, 2005. P.131-150.

12. Washington Teresa. Our mothers, our powers, our texts: manifestations of Aje in Africana literature. Bloomington: Indiana UP, 2005.

УДК 75.03/.04(73)(092):391.8(6)

DOI: $10.24144 / 2617-3921.2020 .18 .250-261$

Lucia Rusinková

Master of Philology, Pavol Jozef Šafárik University in Košice, Faculty of Arts, Department of British and American Studies ORCID ID: https://orcid.org/0000-0001-7550-915X Košice, Slovakia, +421915926900 lucia.rusinkova@student.upjs.sk

\title{
Incorporation of traditional African artifacts in selected works by Loïs Mailou Jones as a reflection of historical identity
}

Анотаиія. У статті здійснено аналіз вибраних творів Лоїс Майлу Джоунз, видатної художниці Гарлемського Відродження. Головним критерієм для відбору послугувала наявність у них рис африканського племінного мистецтва. Мета дослідження полягає в тому, аби довести, щзо згадані артефакти стали для художниџі інструментом, який дав їй змогу 
осмислити нерівне становище афроамериканців у суспільстві, їхню ідентичність, а також спадщчну споконвічної Африки. Отже, дві картини, відібрані для аналізу - «Фетимі» («Les Fetiches») ma «Дві віри» («Two Faiths»), були створені відповідно в кіниі 1930-х та на початку 40-х років. Основна причина чому акцент робиться на иій темі - часта відсутність інформації про образотворче мистецтво Гарлемського Відродження у публікаціях, присвячених сучасному мистецтву. Як виявлясться, образотворче мистецтво Гарлемського Відродження ніколи так високо не поціновувалося, як література чи музика, які представляють ияю епоху. Однак в статті не ставиться завдання простежити чому це так; натомість, тут докладено зусиль, щуоб висвітлити тему, яку часто ігнорують. Важливо зазначити, щуо в статті тема образотворчого мистецтвва розглядається не в рамках теорії мистецтвва, а отже аналіз спирається на історичний контекст та філософські тендениії перших десятиліть ХX століття, щзо дозволило мисткині підійти до поняття ідентичності з унікального ракурсу. Методологія, яка застосовується для дослідження, охоплює описовий метод у поєднанні зі спостереженням за формальними аспектами картин; також изі особливості протрактовуються у вже згадуваному історичному контексті. Тому увага зосереджена радше на смислах картин, простежуваних конотаціях, а не на майстерності виконання. Таким чином, вагомий внесок статті полягає в поглибленому аналізі двох творів, щзо відносяться до Гарлемського Відродження (Негритянського руху) та пов'язаних з ним філософських напрямків перших десятиліть ХХ століття 3 наголошенням на використанні артефактів корінних африканиів. Крім того, запропонований матеріал може пригодитися читачам, які иікавляться досить знехтуваною темою образотворчого мистецтва Гарлемського Відродження.

Ключові слова: ідентичність, Гарлемське Відродження, артефакт, релігія, маски, спадщина

Abstract. This paper deals with the analysis of selected works of Loïs Mailou Jones, a prominent visual artist of Harlem Renaissance. The key element determining the selection of particular works was the presence of African tribal art features in these paintings. The intention was to prove that the mentioned artifacts became a tool for the artist that enabled her to reflect upon the unequal position of African Americans within society, their identity, as well as upon the heritage of the ancestral Africa. Thus, the two works selected for the analysis are Les Fetiches and Two Faiths, produced in the late 1930s and the early 1940s respectively. The main reason the paper focuses on this topic is frequent absence of visual art of Harlem Renaissance in publications dedicated to Modern art. Similarly, the visual art of Harlem Renaissance has never been met with the same level of appreciation as literature or music representative of this era. Yet, it is not the intention to trace reasons why it is so; instead, the paper aims to provide a contribution to this often 
overlooked topic. It is important to say that the paper approaches the theme of visual art not from the perspective of art theory. Instead, the analysis relies on historical context and the philosophical tendencies of the first decades of the $20^{\text {th }}$ century that enabled the artist to approach the notion of identity from a unique angle. To describe the methodology being used, it is a combination of a descriptive method related to observation of formal aspects of paintings, yet, these features are interpreted within the already mentioned historical context. The focus is therefore more on the paintings' meaning, traceable connotations, rather than on the artistry itself. The contribution of the paper thus resides in in-depth analysis of the two works within the framework of Harlem Renaissance, Négritude movement and affiliated philosophical strands of the first decades of the $20^{\text {th }}$ century with the accent on the use of indigenous African artifacts. Moreover, the paper may be also useful to readers interested in frequently unheeded topic of visual art of Harlem Renaissance.

Keywords: identity, Harlem Renaissance, artifact, religion, masks, heritage

Introduction. The incentive for this paper was a strange fact that despite undisputed critical acclaim of the Harlem Renaissance, the visual art of this period has received a rather meager attention in comparison with other genres of artistic creation of this era. While jazz proved to become a turning point in the history of music and in the sphere of literature, considerable success was achieved with significant number of authors having become an inherent part of the canon, the same cannot be said about the field of fine arts. For that reason we have determined to focus on this area, often overlooked within the context of Harlem Renaissance but especially within the context of the Modern art itself. It must be said that it is not the intention of this paper to explain the marginalization of visual art of Harlem Renaissance; however, it will hopefully demonstrate that this art is worth being paid attention to at a greater scale.

In general terms, the paper looks at the notions of identity as understood in terms of history. More precisely, the paper observes how such identity can be regained via art, how art can serve as a means of uplift of a group of people that share an experience of systemic discrimination and finally how art can serve a political purpose. To be more specific, this paper examines the work of Harlem Renaissance painter Loïs Mailou Jones and the use of traditional artifacts, namely masks and fetishes in two of her paintings, Les Fetiches and Two Faiths, and it does so primarily within the context of political beliefs of the first half of $20^{\text {th }}$ century that addressed and eventually offered ideas to improve the unequal position of people of African descent in Western societies. The hypothesis states that the import of traditional African artifacts into Western world in the early $20^{\text {th }}$ century that led to incorporation of tribal art features into Modern art eventually triggered new conception of identity and offered new perspectives, especially for African Americans, to approach the question of their identity and to address the problems of social inequality, predominantly in arts. 
Methodology. The analysis of selected works is realized independently by the means of descriptive method. The formal aspects of the paintings, as the techniques used, the shapes, the use of colors all deserve the attention, yet the major emphasis is put predominantly on the presence of tribal African artifacts by the means of which the painter expressed her view on the question of African American identity, history and the complexities related to their ancestry in relation to the prevailing philosophical and political tendencies of the first half of $20^{\text {th }}$ century; in other words an interpretation of paintings within mentioned context.

Results and Discussion. Throughout her long and prolific career, Loïs Mailou Jones (1905-1998) managed to produce an ample body of work that made her one of the most prominent African American artist of the $20^{\text {th }}$ century. Jones is generally associated with the period of Harlem Renaissance, even though it must be said that her most distinguished works were produced later in her career. The examples presented here represent her work from the late 1930s until the early 1940s, when she began producing her most mature works. First, however, it is necessary to clarify the term 'Harlem Renaissance' itself. We can define it as an outburst of arts and cultural activity among African Americans that started after WWI and ended in the early 1930s once the Great Depression put a halt to it. Generally it does not comply to the requirements of an artistic movement as such; it cannot be characterized by one major style since the art of Harlem Renaissance encompasses large variety of styles and approaches. The unifying element is therefore not an inclination to a certain mode or technique; instead, the connecting element is an effort to reconstruct and redefine African American identity. The Black Americans looked back at their history, i.e. the era of slavery and the ancient African past from significantly changed perspective; African heritage became worthy of appreciation as well as their folk heritage, since it demonstrated the capacity of African Americans to create original art forms despite the conditions of the slavery era. Harlem played an important role in this process of rediscovering the lost heritage; it was a place that epitomized the search for a new Black identity and offered efficient ways of spreading these new ideas:

Removed from their place of Southern enslavement, the new Northern blacks sought a new social identity. Harlem afforded a space in which this self-definition could develop, and also gave black intellectuals and political leaders a chance to raise the consciousness of people drawn from all over the South. [2, p. 116]

Jones's formation years as an artist were naturally marked by the emergence of new ideas and shift of perception of their situation among African American themselves.

The beginnings of her career are not in fact connected with the painting. In her twenties she developed an interest in patterns and textile design, which led her to creating costumes for at that time first-rate Denishawn Dance Company. This experience marked a crucial point in her career, as it was while designing the costumes and the masks for this modern dance company that she seriously studied 
African masks and other traditional African art forms for the first time. [5, p. 178] Much later in her life she remarked that this encounter with African art motivated her to incorporate these motifs in much larger scale, and that one of her most famous works Les Fetiches and earlier, in 1928, her cover for the Opportunity magazine, can be ascribed directly to the Denishawn experience. Masks became an emblematic feature of Jones's artistic expression, and throughout her long career she would draw upon the tribal art extensively. As she later remarked, "I found that the African masks gave me my best opportunity for studying the mask as a form, and my interest in the mask began very early in my career. The African mask, you will note, is still very important in my paintings today." [8, p. 357] Jones's work can be characterized by wide spectrum of the rendition of African masks and the two selected works constitute a small sample which aims to outline a variety of possible approaches towards the use of African masks and other artifacts.

One of her most distinguished works is Les Fetiches, painted in 1938 while she was studying in Paris at the Academie Julian. In relation to Les Fetiches, it seems indispensable to mention the crucial impact of Paris on her life and career. Her stay in Paris completely changed the perspective of herself as an artist and strengthened her self-confidence:

I would walk into those openings of the exhibits and see the paintings of Loïs Jones hanging beside those of artists from all over France and all over the world, as a matter of fact. It gave me the strength to realize my talent and that I really had the ability to succeed. It was my chance to compare my work with that of the great artists in France... France gave me my stability, and it gave me the assurance that I was talented and that I should have a successful career. [8, p. 360-361]

Inspired by Henry O. Tanner and encouraged by her close friend Meta Warrick Fuller, another crucial figure of the Harlem Renaissance, who studied in Paris under Auguste Rodin and gained considerable recognition, for Jones it was also a logical step to move to Paris. In the 1989 interview she summed up the significance of Paris on her life and career with the following words: "Freedom. To be shackle free. That's the thing that released you from all of the pressure and stagnation which we suffered in this country." [8, p. 359]

Jones herself admitted that Les Fetishes marked "a major point of her career." The inspiration for this painting she found in the Paris galleries, where she observed various fetishes and masks and drew the sketches which she reworked into this painting. Among the range of her works, Les Fetishes protrudes due to its bold design and the macabre atmosphere it evokes. It could be said that the rendition of masks approximates to the actual nature and function of tribal masks. While it is true that the use and the form of masks (which can be traced back to Paleolithic age) varied depending on the particular African region, some parallels can be observed among all the African cultures, despite their diversity. The traditional function of masks was primarily related to religious beliefs and practices; they were perceived 
as a medium between the people and a God-like entity, or in general, the world of the spirits. It was often believed that the masks represented a spirit of an ancestor; even more so, that the person who wears the mask is possessed by this spirit. The excessive stylization can be explained by traditional belief which puts an emphasis on the distinction between the essence and the surface of reality; hence the stylization that refers to the abstract nature of the reality that is not visible. [7, p. 188-191]

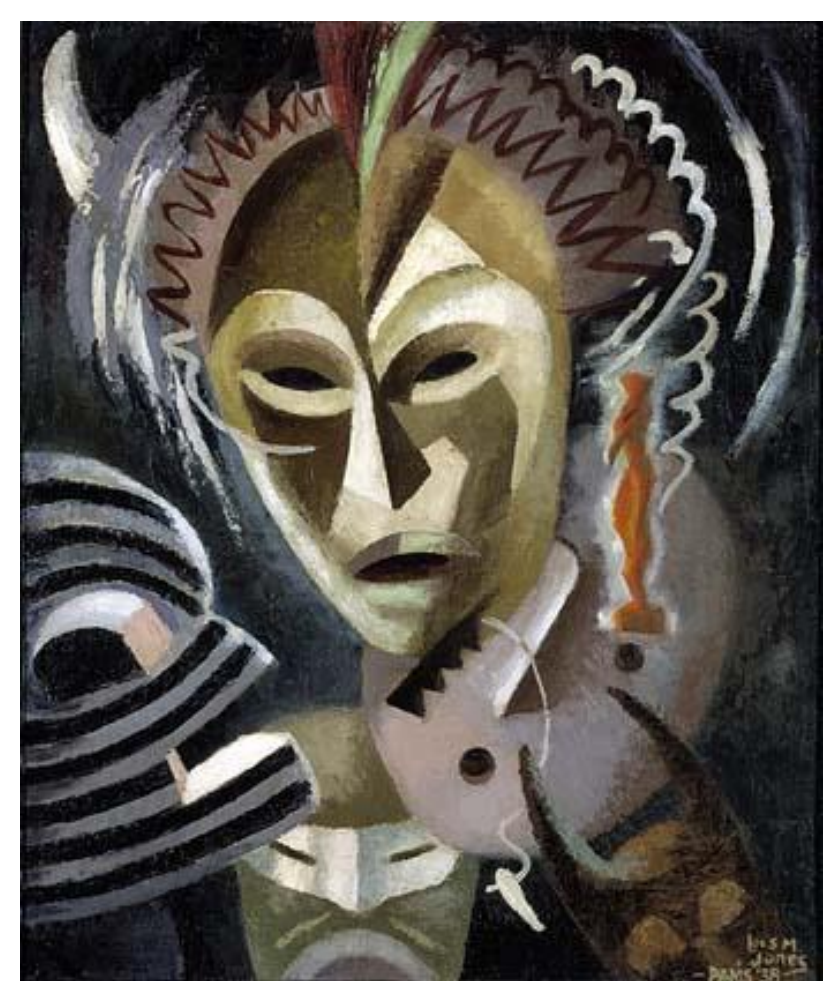

Fig. 1 [Les Fetiches, 1938, oil on linen]

It could be said that certain degree of realism is applied in the depiction of masks. To put it more precisely, the stylization stems from the masks themselves as physical objects and their rendition on the canvas reflects their true form. This painting also includes exclusively five overlapping masks, each unique in form which might be understood as a representation of different African tribes or a groups.

Additionally, there is a sense of rhythmic pulsation achieved by the positioning of the masks, their size and the use of color. Even though rather muted, the color spectrum is composed of earthy colors oscillating predominantly between grey and brown tones. Perfectly balanced composition abounds with color nuances of the masks, which, in combination with the dark black background endow the painting with an illusion of a depth.

Apparently, in Les Fetiches, the reference to Africa is straightforward. Africa is conceived here as a mythic place; the aura of mysticism radiates from the whole painting. Seemingly, in a way, it evokes the Eurocentric images of Africa as a dark continent, of rituals the comprehension of which is elusive for Western understanding. The spirituality invoked here transcends established Western 
conception of religious experience. In terms of style, the African traditional and modern Cubist aesthetic (or rather Post-Cubist, given the fact that the painting was created more than two decades after Cubism reached its peak) meet in mutual harmony; the angularity of forms derives from the nature of the masks themselves yet in effect fits well within modernism as well, the very modernism that made extensive use of these features.

By then, Jones overtly embraced the African heritage as one of the major sources of inspiration for her art works and as the expression of her identity. Referring to Les Fetiches she stated the following:

I did that painting in Paris in 1937. I remember taking it down to the Academie Julian to my professors: they all looked at it, they looked at me, and they said, "Mademoiselle Jones, it does not look like you. You paint the Luxembourg Gardens and the Cluny Gardens and the streets of Paris. What are you doing?" So I said, "Well, when you look at Matisse and Picasso and Modigliani and all the others using the African influence, don't you think that if anyone has the right to use it I should have the right? " [8, p. 367]

Taking into consideration the fact that Les Fetiches was created in Paris, it is necessary to analyze the painting also from the perspective of philosophical and political tendencies emerging from France, i.e. the Négritude movement. Having been led by francophone intellectuals Aimé Césaire and Léopold Senghor, it was a philosophy that originated in the 1930s as a reaction against the French colonialism and that called for the unity of all the people of African origin. Négritude is mostly associated with poetry and philosophy; nevertheless it found response also in visual art. As Souleymane Bachir Diagne stated,

Senghor wanted Négritude to be the philosophy of the geometrical forms so characteristic of African masks and sculptures across different regions and cultures. He would often explain that the raison d'être of art in Africa is not to reproduce or embellish reality but to establish the connection with what he labelled the sub-reality that is the universe of vital forces. What modern art understood from the consideration of art nègre is that the issue was not anymore to simply reproduce sensible appearances but to deal with the forces hidden beneath the surface of things. [4]

It is symptomatic that in Senghor's conception, the masks represented a unifying symbol of the people of African ancestry. First, it is an element that reoccurs throughout all the variety of African culture, therefore it functions as a connecting element that enhances the diasporic nature of Négritude. To a great extent, Les Fetiches is a reflection of Négritude philosophy; even its realization in visual form. Moreover, the masks, each being different in form and color, might be 
read as an expression of unity of African diaspora connecting the underlying philosophy of Negritude and the Harlem Renaissance in her own, distinctive style.

The following painting, Two Faiths, also offers a noteworthy interpretation of the legacy of the African heritage in relation to Western tradition. Created in 1944, the work reflects the period of Jones's career, during which her preoccupation for African heritage was shaped further, partially also due to Alain Locke's involvement. As she recalled,

When I came back from France, the first person I met on the campus at Howard University was Dr. Alain Locke, who greeted me by saying that he had followed my career in Paris and that he was using one of my paintings, a street scene in Montmartre, in his book. But he insisted that black artists have to do more with the black experience and, especially, with their heritage. He brought up the fact that Matisse and Modigliani and Picasso and so many of the French artists were getting famous by using the African influence in their work and that it was really our heritage and that we should do something about it. What Dr. Locke said caused me to turn to the black subject... [8, p. $358]$

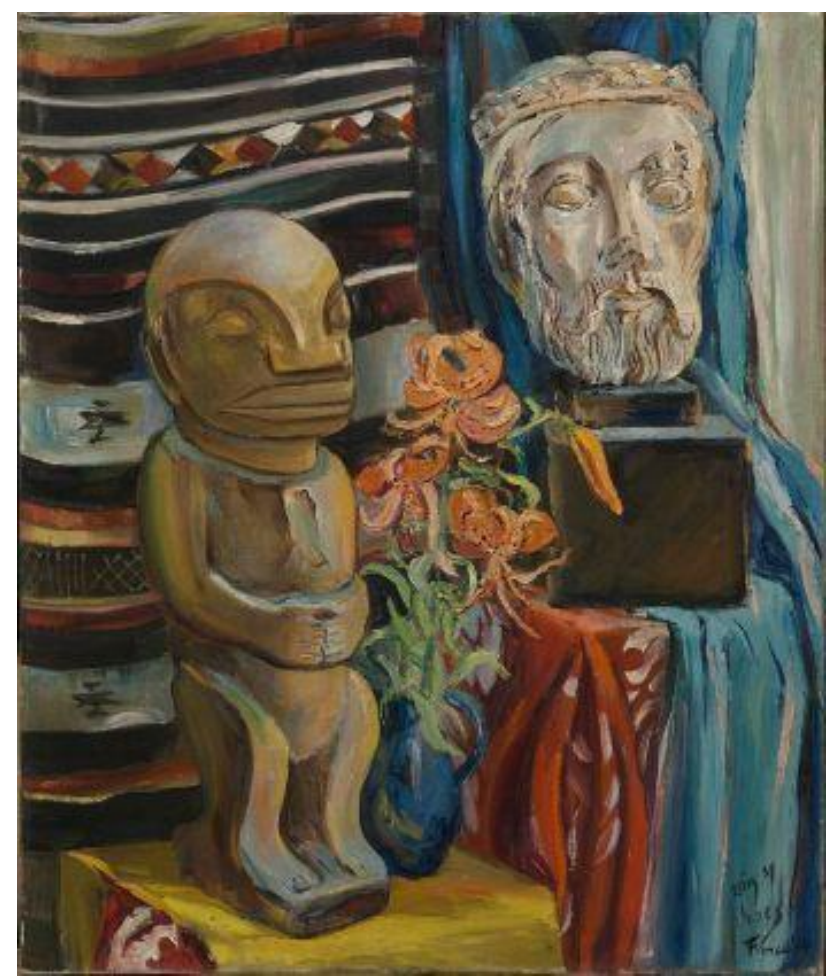

Fig. 2 [Two Faiths, 1944, oil on canvas]

The importance of Alain Locke, prominent African American scholar deserves to be mentioned in this context; this philosopher, educator and an aesthete was a crucial figure of the Harlem Renaissance and his publications also prompted the embracement of African legacy. In his essay, The Legacy of the Ancestral Arts he expresses a belief that the Black people brought to America their "deep-seated aesthetic endowment" and that the art of their African ancestors is also their cultural heritage which, in order for Black American artists to produce a true and honest 
work reflecting the complexities of African Americans reality, must be embraced. Locke is fully aware of the fascination of the white world with 'exotic', African masks and fetishes and he believes that that the Black artists might in fact benefit from this situation. He suggest that in terms of art, and perhaps even beyond this sphere, there is much closer affinity between African America and Europe; while in America a Black person had always been a figure of neglect and ridicule, in Europe the tradition of true interest in him can be traced back as far as to French Romanticists. [6, p. 262]

To some extent, the title Two Faiths is self-explanatory as the core of the message the painting conveys is the awareness of the discrepancy between the two cultural grounds which is expressed on the level of the subjects portrayed as well as on the formal level. Similarly as in Les Fetiches, in Two Faiths the portrayal of the indigenous African art transcends mere stylistic inspiration since the central idea is drawn upon the function of the selected object; in this particular example an African fetish and a classical bust, acquiring a symbolic meaning.

The composition is strictly divided into two parts allegorically representing the 'two faiths'. The very title is a noteworthy indicator of the thematic concept of the painting. In fact, the work deals profoundly with the notion of religion, specifically, with the striking difference between African and Western (European) religious grounds. The difference is expressed by a line palpably dividing separating the composition into two, strikingly varied parts. While Les Fetiches is characterized by balanced positioning of the subjects evoking a sense of harmony, Two Faiths echoes severe discord. The division is expressed on three basic levels; on the level of the subject portrayed, the color spectrum and the clash between horizontal and vertical lines. The left 'African' side of the composition depicts a wooden African idol or a fetish which occupies significant part of the whole painting. The shapes of the artifacts are considerably simplified with certain degree of angularity enhancing exaggerated features of mouth, eyebrows, and the nose. The stylization is therefore, emitted from the object itself. Within the framework of African indigenous religious tradition, the idols had a function that in simple terms could be described as an intermediary between the people and the supreme entity. The idols were an item to be worshipped, yet the ultimate object was the Supreme Being, i.e. the deity represented by the artifact. The function of the idol is therefore purely symbolic embodying the divine being. Furthermore, the idol, given its representative purpose aids, as J.O.Awolalu put it, "man's perception and concentration and to remind the worshipper of the divine presence." [1, p. 8] Moreover, the fetishes and the idols are connected with power, which either resides in them or a fetish itself contains the power implemented in ceremonial consecrations. [3, p. 146] In the painting, the specificity of African religious experience is further underpinned by other constituting features. The drape forming the background of the left part is characterized by colorful horizontal stripes. Again, the spectrum is composed of predominantly earthy colors sprawling from white, yellow, orange and red to deep black tones. The fabric also contains geometric patterns so typical for African 
decorative arts. A sense of warmth emanates from this part of the composition which aims to turn the attention to energy and vivacity of African religious experience. Jones spent considerable part of her artistic studies in Europe, therefore the education she received was based on modern Western standards. Yet, in order to gain recognition she did not succumb to the established academic requirements and even though the tribal art motifs were by then well acknowledged as a valuable contribution to modernism, the critics and many artists as well still maintained that tribal art itself does not surpass the established Western standards. To a great extent, these motifs still played a role of a curiosity that, in order to perform a certain function must be put into perspective of modern art. Jones breaks away from such view by juxtapositioning the traditional African with classical European (or rather seemingly medieval), but not modern, referring to the grounds of Western culture. Addressing the question of the Western tradition as a de facto a synonym of civilization, it is possible to read in the painting at least some degree of subversion. The elevated position of this 'one and only' civilization is indicated by the pedestal of the bust being placed above the African idol. The contrast between 'high' Western and 'low' ancient African culture is therefore expressed directly in the placement of the statues.

The issue of inferiority vs. superiority of given religions and cultures should not be conceived merely on an abstract level; for centuries the African religious tradition had been systematically suppressed by the colonists. The process of implementation of Christianity had been accompanied by destruction of the worship of 'pagan' idols and fetishes, which, in fact, was made punishable. Nonetheless, the very religious practices the Christianity found obnoxious paved the way to its successful implementation. To be more specific, both cultures made use of icons or images. According to Hartmut Böhme, "Christian customs were understood in exactly the same way by the Africans as pagan sacred objects, amulets and private fetishes were by the missionaries: as instruments of magic." [3, p. 142] Subsequent massive Christianization almost annihilated traditional religious beliefs and practices by de facto substituting them with Catholic customs. Two Faiths therefore also addresses the issue of colonization that strongly affected African religious tradition. Undoubtedly, religion significantly forms one's identity as well as identity of a nation; it is a strong cultural constituent. Jones's conception of African identity therefore logically aims to rediscover, re-embrace old religious traditions which, in her understanding, as the painting suggests, indicates a sense of irreconcilability with the Western Christian tradition.

Indeed, in opposition to vivacity of the African part of the composition the Western side evokes certain rigidness and coldness. The use of light blue color for the drape is the source of striking contrast. The bust might be understood as a symbol of dignity and sophistication of Western culture, yet, given this context, it can also be read as an indicator of severity of this tradition.

Within the context of African American history, Two Faiths addresses the problematic issue of what the African Americans should 'believe in;' i.e. how to 
reconcile the contradictions between their heritage and their American identity as they were met with a challenge of re-invention of their identity that started in the 1920s during the Harlem Renaissance. Two Faiths points out this issue by literally putting the tradition of the two continents next to each other and by marking the strict separation the painting expresses a sense of divergence, a duality of lived experience, the 'double consciousness' as W.E.B DuBois would describe it. More importantly, though, the painting encourages the African Americans to re-establish the lost connection with Africa and to reflect on African heritage.

Unsurprisingly, Two Faiths also visualizes Négritude philosophy that also perceives the African and the Western as clashing concepts:

The mystic warmth of African life, gaining strength from its closeness to nature and its constant contact with ancestors, should be continually placed in proper perspective against the soullessness and materialism of Western culture; that Africans must look to their own cultural heritage to determine the values and traditions that are most useful in the modern world. [9]

More importantly though, the lack of permeation might be interpreted as the need to create space for the African cultural heritage in the modern world, i.e. within the dominant cultural environment that sees itself as more distinguished.

To conclude the analysis of this particular painting, in Two Faiths two principles meet - The Négritude and the philosophy of the Harlem Renaissance, namely that of Alain Locke as both being based on common grounds with their emphasis on African spirituality, even mystic dimension of personality of people of African descent. This conception is intertwined with the issue of religion as a pillar of identity, in this case the African idolatry and fetish worship, which can be conceived as a possible way to comprehend the African heritage.

Conclusion. It is obvious that Jones drew extensively on various philosophical and even political ideas that sprung up during the $1^{\text {st }}$ half of the $20^{\text {th }}$ century and in a sense her works are products of their age. If we wanted to be simplistic we might even say that the paintings analyzed might be read as a theory put into artistic practice. Such interpretation would be misleading, though, and it would make her works ideological and dogmatic. Both paintings are a demonstration of a communion of several opposite principles. They are direct in addressing their theme, yet, this fact does not make them one-dimensional in their interpretation. As we have seen, the opposite is true, as there layers of meaning to be discovered. Furthermore, the analysis showed that both paintings conjoin aesthetic principles with intellectual endeavor since the impact of philosophical tendencies is palpable. Both works are aesthetically appealing to a viewer, yet, the awareness of philosophical, political ideas of the era when the works were being made enriches their understanding and allows more complex interpretation.

This is achieved by using the elements the paper focuses on as not mere aesthetic objects; the crucial feature is the awareness of their function. In that sense, 
her rendition of tribal arts features aims to highlight their original, i.e. religious purpose. The employment of religion as a motif proved to be appropriate and fruitful way of reflecting upon the social reality of African Americans as well as her Jones's lived experience as an artist. Indeed, it seems to be legitimate to describe these works as a reflection or even as a dialogue with the past and the present and their impact on one's identity. In both works, but especially in Two Faiths Jones offered a meaningful commentary on two civilizations, the Western and the ancient African; their rivalry and the perils of their erasure from history.

One's identity cannot be divorced from one's history as both paintings showed, and so we can conclude that hypothesis which stated that the tribal arts elements that was met with astonishment in the Western world and mostly in Modern art world of the first decades of the $20^{\text {th }}$ century eventually offered new ways, new language to describe the experience of African American and to address the question of their identity in artistic form.

\section{LITERATURE}

Primary sources:

Jones Loïs Mailou. Les Fetiches. 1938, Smithsonian American Art Museum, Washington DC url= http://americanart.si.edu/collections/search/artwork/?id= 31947 JONES Loïs Mailou. Two Faiths. 1944. Museum of Fine Arts Boston, Boston, Massachusetts url= http://www.mfa.org/collections/object/two-faiths-paris490909

Secondary sources:

1. Awolalu J.O. What is African Religion Tradition? Studies in Comparative Religion. Vol. 9, no. 1, 1976. url=http://www.studiesincomparativereligion. com/public/articles/What_is_African_Traditional_Religion-by_Joseph_ Omosade_Awolalu.aspx

2. Birch A.L. Harlem and the First Black Renaissance. Harold Bloom: The Harlem Renaissance. Chelsea House Publishers, 2004.

3. Böhme H. Fetishism and Culture: A Different Theory of Modernity. De Gruyter, 2014

4. Diagne Souleymane Bachir. Négritude. The Stanford Encyclopedia of

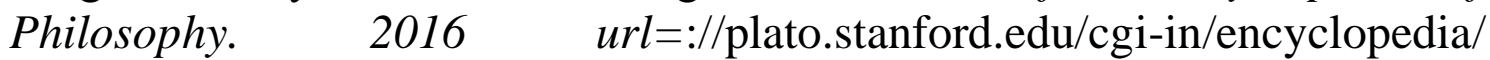
archinfo.cgi?entry=negritude

5. Earle S. The Wide-Ranging Significance of Lois Mailou Jones. Women Artists of the Harlem Renaissance. University Press of Mississippi. 2014

6. Locke A. L. The New Negro: An Interpretation" Johnson Reprint Corporation, 1999

7. Middleton J. New Encyclopedia of Africa. Vol. 1, Charles Scribner \& Sons, 2007

8. Rowell Ch. H. An Interview with Lois Mailou Jones. Callaloo. No. 37, 1989 $u r l=: / / \mathrm{www} . j \mathrm{stor} . o r g /$ stable/2931576?seq=1\#page_scan_tab_contents

9. Encyclopaedia Britannica. "Negritude" Encyclopaedia Britannica, 2002 url= https://www.britannica.com/topic/Negritude 